\title{
MODEL KONSEPTUAL KINERJA INDIVIDUAL PEGAWAI PEMERINTAH DAERAH KABUPATEN YANG BERBASIS KOMPETENSI, KOMITMEN ORGANISASI, DAN MOTIVASI KERJA
}

\author{
I Wayan Bagia ${ }^{1}$, Fridayana Yudiaatmaja ${ }^{2}$, Ni Nyoman Yulianthini ${ }^{3}$ \\ 1,2,3 Universitas Pendidikan Ganesha \\ Singaraja, Indonesia
}

Email: bagia@yahoo.com

\begin{abstract}
Abstrak
Tujuan penelitian ini adalah untuk memperoleh temuan (1) faktor-faktor atau dimensi yang membentuk konstruk kinerja, kompetensi, komitmen organisasi, dan motivasi kerja;dan (2) model koseptual kinerja individu pegawai yang berbasis kompetensi, komitmen organisasi, dan motivasi kerja. Penelitian ini menggunakan desain penelitian studi pustaka dan survei. Penelitian survei dilakukan pada delapan kabupaten, yaitu Kabupaten Jembrana, Tabanan, Badung, Gianyar, Bangli, Klungkung, Karangasem, dan Buleleng dengan menggunakan teknik penarikan sampel stratified random sampling. Data dikumpulkan dengan metode pencatatan dokumen, wawancara, dan kuesioner, kemudian dianalisis secara deskriptif dan menggunakan SEM (Structural Equition Modelling) untuk melakukan pengujian secra empirik. Temuan hasil analisis deskriptif dan SEM menunjukkan bahwa (1) konstruk variabel kinerja pegawai dibentuk oleh dimensi kuantitas kerja, kualitas kerja, pengetahuan kerja, kreativitas, kerja sama, inisiatif, dan kualitas personal; konstruk variabel kompetensi pegawai dibentuk oleh dimensi kompetensi intelektual, sosial, emosional dan spiritual; kontruk variabel komitmen organisasi dibentuk oleh dimensi komitmen organisasi afektif, kontinyu, dan normatif; serta motivasi kerja dibentuk oleh dimensi gaji, pekerjaan itu sendiri, promosi, rekan sekerja, dan kondisi kerja; dan (2) model konseptual kinerja individu pegawai dipengaruhi oleh kompetensi dan komitmen organisasi dengan motivasi kerja pegawai sebagai intervening.
\end{abstract}

Kata kunci: kompetensi, komitmen organisasi, motivasi kerja, kinerja

\begin{abstract}
The aims of research are to get the finding of: (1) factors or dimensions that composed the variable contructs of performance, competency, organizational commitment, and work motivation; and (2) the employee's indidual performance conceptual model that was based on the competency, organizational commitment, and work motivation. This research used the literature study and survei design that had been done in eight regencies, namely: Jembrana, Tabanan, Badung, Gianyar, Bangli, Klungkung, Karangasem, and Buleleng by using stratified random sampling technique. The data were collected by document administration, interview, and questionnaire as the research technique. Descriptive and structural equition
\end{abstract}


modelling are the method of analysis to excute of the hypotheses testing. The result of descriptive and structural equition modelling analysis shows that (1) the variable construct of performance had been composed by dimensions of work quantity, work quality, job knowledge, creativity, cooworker, initiative, and personal quality; the employee competecy construct variable had been composed by competency dimensions of intellectual, social, emotional, and spiritual; organizational commitment variable construct had been composed by affective, continue, and normative organizational commitment dimensions; and work movation variable construct had been composed by pay, work itself, promotion, cooworker, and work condition; dan (2) the employee individual performance conceptual model had been influenced by competency and orgnizational commitment with the employee work motivation as intervening.

Keywords: competency, organizational commitment, work motivation, performance

\section{PENDAHULUAN}

Lembaga pemerintah daerah merupakan organisasi nonlaba (nonprofit oriented organization) yang tugasnya menjalankan fungsi (1) memberikan pelayanan, (2) pengaturan, (3) pembangunan, (4) perwakilan, dan (5) koordinasi dan perencanaan (Supriatna, 1996). Dalam menjalankan fungsi pemberian pelayanan kepada masyarakat, perlu dilakukan integrasi yang terpadu di antara pemerintah sebagai penyedia pelayanan, pegawai sebagai pelaksana pelayanan, dan masyarakat sebagai penerima atau pemakai pelayanan (Mochammad, 2000). Pelayanan yang diberikan kepada masyarakat bisa pelayanan yang bersifat fisik maupun administratif (Munir, 1998).

Temuan penelitian yang

dilakukan pada Center of Population and Policy Studies (2000) menunjukkan bahwa produktivitas pegawai negeri sipil di Indonesia masih sangat rendah, yaitu baru mencapai angka produktivitas rata-rata $51,40 \%$. Fakta ini memberikan indikasi secara implisit bahwa kinerja pegawai pemerintah daerah kabupaten di Bali masih relatif rendah karena pegawai pemerintah daerah kabupaten di Bali juga termasuk pegawai negeri sipil dan dijadikan sampel dalam penelitian ini. Di samping itu, belum tercapainya target kinerja pelayanan pemerintah daerah kabupaten seperti yang diharapkan oleh pemerintah pusat diduga karena masih relatif rendahnya kompetensi sumber daya manusia, komitmen pegawai terhadap organisasi (Tjiptoherijanto, 2001), dan tingkat motivasi kerja pegawai (Taringan, 2003). Padahal kompetensi, komitmen organisasi (Burr dan Girardi, 2002) dan motivasi kerja (Palan, 2007) berperan penting dalam membentuk kinerja pegawai yang pada akhirnya akan menciptakan kualitas pelayanan yang superior kepada pelanggan.

Tujuan penelitian ini adalah untuk memperoleh temuan: (1) faktorfaktor atau dimensi yang membentuk konstruk kinerja, kompetensi, komitmen organisasi, dan motivasi kerja dan (2) model koseptual kinerja individu pegawai yang berbasis kompetensi, komitmen organisasi, dan motivasi kerja. yang dapat digunakan untuk

Jurnal IImu Sosial dan Humaniora |510 
meningkatkan kinerja pegawai pemerintah daerah kabupaten di Bali.

Bar-On (2000) menyatakan bahwa kinerja adalah tingkat penyelesaian tugas-tugas yang merupakan pekerjaan karyawan. Konsep kinerja yang dinyatakan oleh ketiga ahli ini masih sangat lemah karena baru melihat kinerja pada aspek kuantitas pekerjaaan yang diselesaikan oleh karyawan dan belum melihat aspek kualitas yang melekat pada personal karyawan seperti pengetahuan kerja, pengalaman kerja, dan kemandirian dalam bekerja. Newstrom and Davis (2000) alam teori kinerjanya mengungkapkan bahwa kinerja potensial seseorang dipengaruhi oleh kompetensi yang dimilikinya. Ainsworth et al. (2002) juga mendefinisikan bahwa kompetensi individu adalah kapasitas dari pengetahuan, keterampilan, dan sikap yang dimiliki oleh seorang karyawan yang relevan dengan standar pekerjaan yang akan dilakukan sehingga mampu melaksanakan pekerjaan yang telah dirancang bagi dirinya baik untuk saat ini maupun di masa yang akan datang. Burr and Girardi (2002) mengukur kompetensi pengawai dengan menggunakan tingkat pengetahuan, keterampilan, dan tingkat pendidikan pegawai. Di samping itu, Robbins (2001) juga mengatakan bahwa kompetensi intelektual adalah kemampuan yang diperlukan untuk menjalankan kegiatan mental. Keempat ahli di atas belum mengungkapkan secara rinci unsur atau dimensi apa yang membentuk kompetensi intelektual pegawai.

Kompetensi emosional adalah karakter sikap dan perilaku atau kemauan dan kemampuan untuk menguasai diri dan memahami lingkungan secara objektif dan moralis sehingga pola emosinya relatif stabil ketika menghadapi berbagai permasalahan di tempat kerja yang terbentuk melalui sinergi antara watak, konsep diri, motivasi internal serta kapasitas mental/emosional pengetahuan 2002). Goleman (1998) juga mempertegas bahwa kompetensi emosional sebagai sebuah kemampuan mengenali dan mengelola emosi diri sendiri dengan baik, mampu menganali emosi orang lain, dan mampu menjalin hubungan positif dengan orang lain agar menghasilkan kinerja pada suatu pekerjaan tertentu. Medisiswanti (2001, dalam Pidada, 2001) mengatakan bahwa kompetensi emosional adalah kemampuan untuk mengenali emosi diri sendiri dan orang lain, memotivasi dan mengelola emosi dengan baik pada diri sendiri, dan membina relasi dengan orang lain. Hal senada dengan ini juga diungkapkan oleh Susilo (2003) kecerdasan emosional adalah kemampuan seseorang untuk mengenali, membangkitkan, dan mengelola emosinya.

$$
\text { Kompetensi sosial adalah }
$$

karakter sikap dan perilaku atau kemauan dan kemampuan untuk membangun simpul-simpul kerja sama dengan orang lain yang relatif bersifat stabil ketika menghadapi permasalahan di tempat kerja yang terbentuk melalui sinergi antara watak, konsep diri, motivasi internal serta kapasitas pengetahuan sosial (Spencer \& Spencer, 1993). Topping et al. (2000) juga mempertegas bahwa kompetensi sosial merupakan kepemilikan dan penggunaan kemampuan untuk 
mengintegrasikan pemikiran, perasaan, dan perilaku untuk mencapai tugastugas sosial dan hasil-hasil yang bernilai dalam konteks kelompok dan budaya yang besar.

Kompetensi spiritual adalah karakter dan sikap yang merupakan bagian dari kesadaran yang paling dalam pada seseorang yang berhubungan dengan kebijaksanaan/ kearifan yang berasal dari luar ego (diri sendiri) atau di luar pemikiran sadar yang tidak hanya mengakui keberadaan nilai tetapi juga kreatif untuk menemukan nilai-nilai baru (Zohar and Marshall, 2000). Susilo (2003) juga mengungkapkan bahwa kecerdasan spiritual adalah kemampuan untuk mencari dan menemukan makna tertinggi dengan bantuan kecerdasan intelektual dan emosional serta kemampuan untuk memahami sistem nilai yang berlaku pada orang atau sekelompok orang. Zohar \& Marshall dan Susilo juga belum menawarkan dimensi apa yang dapat digunakan untuk mengukur konstruk kompetensi spiritual.

Komitmen organisasi merupakan perwujudan dari kerelaan seseorang dalam bentuk pengikatan diri dengan organisasi yang digambarkan oleh besarnya usaha (tenaga, waktu, dan pikiran) atau semangat belajar yang berkelanjutan untuk mencapai visi bersama. Komitmen organisasi sangat penting dan diperlukan dalam organisasi karena karyawan yang memiliki komitmen yang tinggi pada organisasi akan cenderung memiliki sikap yang profesional dan menjunjung tinggi nilainilai yang telah disepakati. Seniati (2001), Wall et al. (1999:), dan Cohen (1999: 287) mengatakan bahwa komitmen organisasi itu terdiri dari tiga komponen, yaitu (a) komitmen afektif (affective commitment), (b) komitmen kontinyu (continuance commitment), dan komitmen normatif (normative commitment). Para pakar ini juga belum menjelaskan secara rinci indikator yang digunakan untuk mengukur komitmen afektif, kontinyu, dan komitmen normatif. Motivasi kerja adalah rangkaian yang meliputi satu atau lebih persyaratan yang bergerak untuk mengubah dan memelihara perilaku agar berani bersikap untuk mencapai tujuan atau sasaran yang diinginkan (Witting dan Belkin, 1977). Santrock (1999) melihat ranah motivasi ada dua, yaitu (1) motivasi intrinsik adalah keinginan dari dalam diri seseorang untuk melakukan sesuatu bermanfaat bagi dirinya; dan (2) motivasi ekstrinsik adalah keinginan untuk melakukan sesuatu yang lebih dipengaruhi oleh faktor-faktor yang berasal dari luar dirinya. Di samping itu, Ranto (2007) juga mengungkapkan bahwa motivasi adalah sesuatu hal yang merubah kita dari rasa jenuh menjadi rasa tertarik yang juga memberi semangat dan membimbing aktivitas kita.

Dalam arti luas, motivasi juga menjelaskan istilah lain meneganai pengaruh-pengaruh dari energi dan arah dari perilaku terhadap kebutuhan, minat-minat, nilai-nilai dan sikap seseorang terhadap aktivitas atau peristiwa (Ranto, 2007). Di sisi lain, Owen (1991) mengungkapkan bahwa motivasi bukanlah perilaku melainkan pernyataan internal yang kompleks yang tidak dapat dipelajari secara langsung tetapi pernyataan internal yang kompleks itu mempengaruhi perilaku. 
Hasil studi pustaka yang baru dilakukan menemukan bahwa teori motivasi dapat dibedakan menjadi tiga kelompok besar, yaitu: (1) teori konten (content theory), (2) teori proses (process theory) dan (3) teori penguatan (reinforcement theory) (Schermerhorn, 1996). Teori konten mengungkapkan bahwa motivasi individu disebabkan oleh adanya kebutuhan. Dengan kata lain, teori ini menegaskan bahwa motivasi timbul karena adanya keinginan untuk memenuhi kebutuhan. Semakin banyak kebutuhan yang terpuaskan maka kebutuhan individu akan semakin meningkat. Teori proses berpendapat bahwa tingkat motivasi tergantung pada proses interaksi antara atasan dengan bawahan yang dipengaruhi oleh harapan, preferensi, penghargaan, dan keadilan yang tercipta. Teori penguatan menunjukkan bahwa motivasi itu dipengaruhi oleh proses belajar. Pada saat timbul perasaan menyenangkan dalam diri individu maka akan terjadi proses penguatan. Sebaliknya apabila timbul perasaan yang tidak menyenangkan maka motivasi akan menurun. Hal yang perlu diperhatikan berdasarkan teori ini adalah mempertahankan penguatan yang lebih banyak. Penguatan dapat dilakukan melalui positive reinforcement, negative reinforcement, dan punishment extinction.

Soetjipto (2002) mengatakan bahwa ada kaitan yang positif antara kompetensi dengan kinerja, sehingga diharapkan dengan memacu kompetensi maka kinerja akan dapat ditingkatkan. Di samping itu, menurut Becker et al. (2001) kompetensi yang berhubungan dengan pengetahuan, keterampilan, kemampuan atau karakteristik personal individu berpengaruh langsung terhadap kinerja karyawan. Ben-Bakr et al. (1994) juga mengungkapkan bahwa komitmen organisasi berpengaruh positif dan signifikan terhadap motivasi kerja karyawan. Patterson et al. (1997) mempertegas bahwa komitmen karyawan pada organisasi dan kontrak psikologis yang positif merupakan dasar untuk memperbaiki kinerja baik pada tingkat individu, tim maupun organisasi. Di samping itu, Wall et al. (1990) juga mengungkapkan bahwa karyawan yang memiliki kompetensi dan komimen organisasi yang tinggi dengan didukung motivasi kerja yang tinggi akan meningkatkan kinerja individu karyawan. Ranto (2007) mengungkapkan bahwa ada hubungan positif dan signifikan dari motivasi kerja terhadap kinerja. Hal ini berarti seorang pekerja yang memiliki motivasi kerja yang tinggi akan dapat memelihara perilaku melalui keterampilan dan etika kerjanya untuk menacapai sasaran dan tujuan yang diinginkan sehingga akan memberikan ekspresi positif yang berbasis pada pemikiran dan perasaannya.

\section{METODE}

Penelitian ini menggunakan desain penelitian studi pustaka dan survei. Subjek penelitian adalah karyawan pemerintah daerah kabupaten di Bali yang tersebar di delapan kabupaten, yaitu Kabupaten Jembrana; Tabanan; Badung; Gianyar; Bangli; Klungkung; Karangasem; dan Buleleng dengan menggunakan teknik penarikan sampel stratified random sampling. Data dikumpulkan dengan metode 
pencatatan dokumen, wawancara, dan kuesioner. Data teoritik mengeni faktor atau dimensi yang membentuk variabel kompetensi, komitmen organisasi, motivasi kerja, dan kinerja pegawai dikumpulkan dengan metode pencatatan dukumen sedangkan data empiriknya dikumpulkan dengan metode wawancara dan kuesioner. Data kemudian dianalisis secara deskriptif kualitatif dan kuantitatif menggunakan Structural Equition Modelling (SEM) untuk melakukan pengujian secra empirik.

\section{HASIL DAN PEMBAHASAN}

Pada bagian ini akan disajikan hasil penelitian mengenai faktor atau dimensi yang membentuk konstruk variabel kompetensi, komitmen organisasi, motivasi kerja, dan kinerja pegawai seperti yang nampak pada Tabel 1, hasil pengujian analisis SEM pengaruh kompetensi dan komitmen organisasi terhadap motivasi kerja dan kinerja serta pengaruh motivasi terhadap kinerja seperti yang nampak pada Tabel 2 dan model konseptual kinerja individu pegawai pemerintah daerah kabupaten yang berbasis kompetensi, komitmen organisasi, dan motivasi kerja seperti yang nampak pada Gambar 1.

Tabel 1 Hasil Estimasi Parameter Faktor atau Dimensi Pembentuk Konstruk Variabel Kompetensi, Komitmen Organisasi, Motivasi Kerja, dan Kinerja

\begin{tabular}{|c|c|c|c|c|c|c|}
\hline Variabel & Parameter & $\begin{array}{l}\text { Loading } \\
\text { Factor }\end{array}$ & $\mathrm{R}^{2}$ & $\begin{array}{l}\text { Error } \\
\text { Variance }\end{array}$ & $\mathrm{p}$-value & Simpulan \\
\hline \multirow{4}{*}{ Kompetensi } & Intelektual & 0,6895 & 0,4754 & 0,5245 & 0,0000 & Signifikan \\
\hline & Emosional & 0,7862 & 0,6181 & 0,3818 & 0,0000 & Signifikan \\
\hline & Sosial & 0,8001 & 0,6401 & 0,3598 & 0,0000 & Signifikan \\
\hline & Spiritual & 0,7962 & 0,4831 & 0,5169 & 0,0000 & Signifikan \\
\hline \multirow{3}{*}{$\begin{array}{l}\text { Komitmen } \\
\text { Organisasi }\end{array}$} & Afektif & 0,6598 & 0,4353 & 0,5646 & 0,0002 & Signifikan \\
\hline & Kontinyu & 0,7681 & 0,5899 & 0,4100 & 0,0000 & Signifikan \\
\hline & Normatif & 0,5752 & 0,3308 & 0,6691 & 0,0003 & Signifikan \\
\hline \multirow{5}{*}{$\begin{array}{l}\text { Motivasi } \\
\text { Kerja }\end{array}$} & Gaji & 0,8121 & 0,6595 & 0,3404 & 0,0000 & Signifikan \\
\hline & $\begin{array}{l}\text { Pekerjaan itu } \\
\text { sendiri }\end{array}$ & 0,5875 & 0,3451 & 0,6548 & 0,0001 & Signifikan \\
\hline & Promosi & 0,7865 & 0,6185 & 0,3814 & 0,0000 & Signifikan \\
\hline & Rekan sekerja & 0,6905 & 0,4767 & 0,5232 & 0,0000 & Signifikan \\
\hline & Kondisi kerja & 0,6406 & 0,4103 & 0,5896 & 0,0000 & Signifikan \\
\hline \multirow{8}{*}{$\begin{array}{l}\text { Kinerja } \\
\text { Pegawai }\end{array}$} & Kuantitas kerja & 0,6258 & 0,3916 & 0,8063 & 0,0000 & Signifikan \\
\hline & Kualitas kerja & 0,6341 & 0,4020 & 0,5979 & 0,0000 & Signifikan \\
\hline & $\begin{array}{l}\text { Pengetahuan } \\
\text { kerja }\end{array}$ & 0,6467 & 0,4182 & 0,5817 & 0,0000 & Signifikan \\
\hline & Kreativitas & 0,7004 & 0,4905 & 0,5094 & 0,0000 & Signifikan \\
\hline & Kemandirian & 0,8056 & 0,6489 & 0,3510 & 0,0000 & Signifikan \\
\hline & Kerja sama & 0,6786 & 0,4604 & 0,5395 & 0,0000 & Signifikan \\
\hline & Inisiatif & 0,6452 & 0,4162 & 0,5837 & 0,0000 & Signifikan \\
\hline & Kualitas personal & 0,7984 & 0,6374 & 0,3625 & 0,0000 & Signifikan \\
\hline
\end{tabular}

Sumber: Hasil Studi Pustaka dan Analisis SEM 
Tabel 2 Hasil Analisis SEM Pengaruh $\mathrm{X}_{1}$ dan $\mathrm{X}_{2}$ Terhadap $\mathrm{X}_{3}$ dan $\mathrm{Y}$ serta Pengaruh $\mathrm{X}_{3}$ Terhadap $Y$

\begin{tabular}{|l|c|c|c|c|c|}
\hline $\begin{array}{c}\text { Parameter } \\
\text { Struktural }\end{array}$ & $\begin{array}{c}\text { Koefisien } \\
\text { Jalur }\end{array}$ & $\mathbf{F} / \mathbf{t}_{\text {hitung }}$ & $\mathbf{F} / \mathbf{t}_{\text {tabel }}$ & Keputusan & Pengaruh \\
\hline $\mathrm{P}_{\mathrm{X} 3 \mathrm{X} 1}$ & 0,4024 & $\mathrm{t}=2,9272^{*}$ & 1,6561 & Menolak $\mathrm{H}_{0}$ & Nyata/signifikan \\
\hline $\mathrm{P}_{\mathrm{X} 3 \times 2}$ & 0,4012 & $\mathrm{t}=5,0235^{*}$ & 1,6561 & Menolak $\mathrm{H}_{0}$ & Nyata/signifikan \\
\hline $\mathrm{R}_{\mathrm{X} 3 \times 1 \times 2}^{2}$ & 0,6120 & $\mathrm{~F}=37,7556^{*}$ & 2,6712 & Menolak $\mathrm{H}_{0}$ & Nyata/signifikan \\
\hline $\mathrm{P}_{\mathrm{YX} 1}$ & 0,4047 & $\mathrm{t}=5,5098^{*}$ & 1,6561 & Menolak $\mathrm{H}_{0}$ & Nyata/signifikan \\
\hline $\mathrm{P}_{\mathrm{YX} 2}$ & 0,2221 & $\mathrm{t}=3,0807^{*}$ & 1,6561 & Menolak $\mathrm{H}_{0}$ & Nyata/signifikan \\
\hline $\mathrm{R}_{\mathrm{YX} 1 \times 2}^{2}$ & 0,3035 & $\mathrm{~F}=51,2439^{*}$ & 2,6712 & Menolak $\mathrm{H}_{0}$ & Nyata/signifikan \\
\hline $\mathrm{P}_{\mathrm{YX} 3}$ & 0,5301 & $\mathrm{t}=7,3440^{*}$ & 1,6561 & Menolak $\mathrm{H}_{0}$ & Nyata/signifikan \\
\hline $\mathrm{P}_{\mathrm{X} 3 \varepsilon 1}$ & 0,7386 & & & & \\
\hline $\mathrm{P}_{\mathrm{Y} 22}$ & 0,6965 & & & & \\
\hline $\mathrm{P}_{\mathrm{Y} \varepsilon 3}$ & 0,8479 & & & & \\
\hline
\end{tabular}

Sumber: Hasil Analisis SEM

\section{Keterangan:}

$X_{1}$

$\mathrm{X}_{2}$

$X_{3}$

Y

$=$ Nyata pada taraf 0,05

$\begin{array}{ll}\mathrm{R}^{2} \mathrm{x}_{3} \mathrm{x}_{1} \mathrm{x}_{2} & =\text { Nyata pada taraf } 0,05 \\ & =\text { Koefisien diterminan dari }\end{array}$

$\mathrm{X}_{1}$, dan $\mathrm{X}_{2}$ terhadap $\mathrm{X}_{3}$
$=$ Kompetensi

$=$ Komitmen organisasi

$=$ Motivasi kerja

$=$ Kinerja
$R_{Y X 1 X 2}^{2}=$ Koefisien diterminan dari $X_{1}$, dan $\mathrm{X}_{2}$ terhadap $\mathrm{Y}$

$\mathrm{P}_{(\text {rho) }} \quad=$ Parameter struktural yang menyatakan pengaruh

$\mathrm{Px}_{\varepsilon} \quad=$ Pengaruh variabel lain terhadap X

$\mathrm{P}_{\mathrm{Y \varepsilon 2}} \quad=$ Pengaruh variabel lain

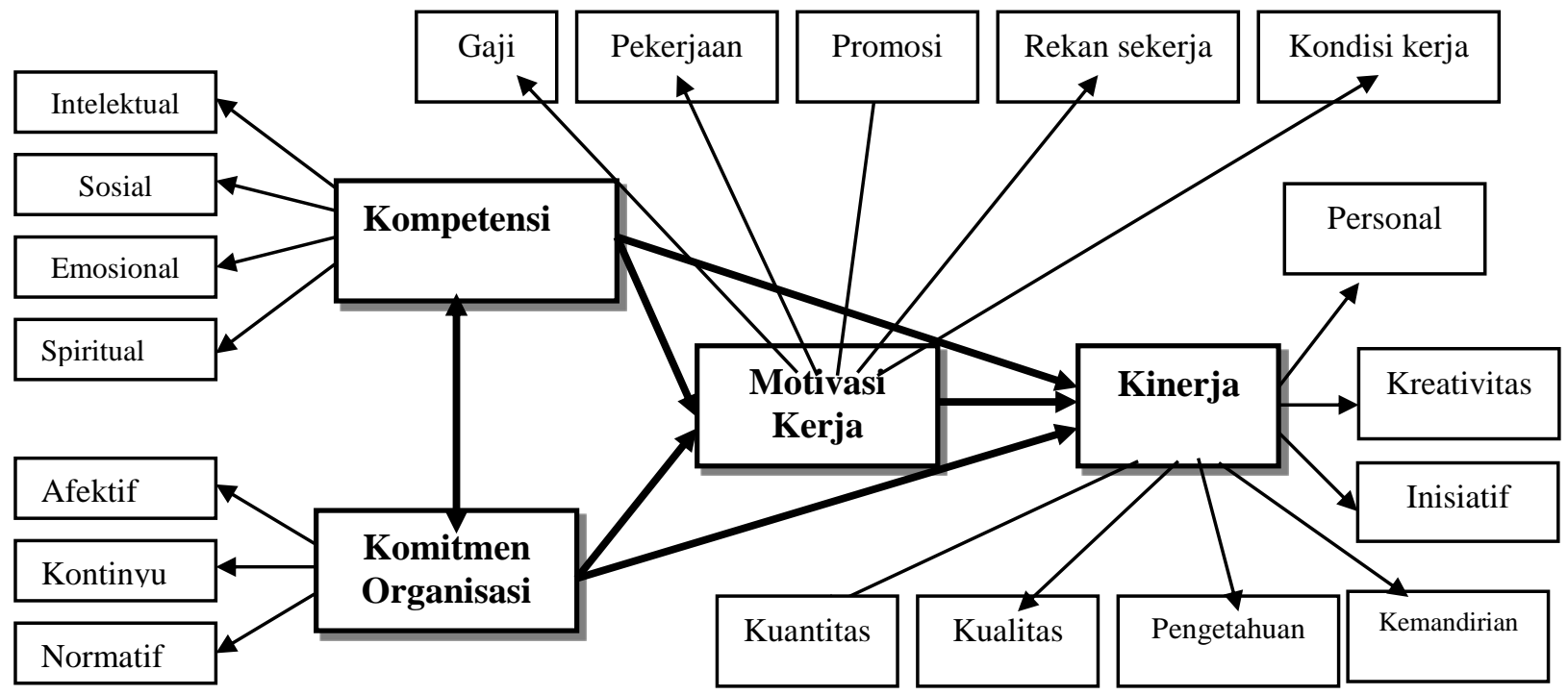

Gambar 1 Model Konseptual Kinerja Individu Pegawai Pemerintah Daerah Kabupaten yang Berbasis Kompetensi, Komitmen Organisasi, dan Motivasi Kerja

Temuan hasil studi pustaka dan analisis SEM pada Tabel 1 mengenai faktor-faktor membentuk atau dimensi yang konstruk variabel 
kompetensi, komitmen organisai, motivasi kerja, dan kinerja individual pegawai sebagai berikut.

(1) Ada empat dimensi yang membentuk konstruk kompetensi, yaitu kompetensi (a) intelektal (b) sosial, (c) emosional dan (d) spiritual. Dimensi kompetensi yang paling dominan menjelaskan variabel kompetensi adalah dimensi kompetensi sosial kemudian diikuti oleh dimensi kompetensi spritual, emosional, dan intelektual..Keempat dimensi ini bisa membentuk konstruk variabel kompetensi pegawai karena melalui interaksi keempat dimensi ini akan bisa meningkatkan kapabilitas, kapabilitas, dan kesempatan yang ada pada personal pegawai dalam melaksanakan pekerjaan.

(2) Ada tiga dimensi yang membentuk konstruk variabel komitmen organisasi, yaitu komitmen organisasi (a) afektif, (b) kontinyu, dan (c) normatif. Dimensi komitmen organisasi yang paling dominan menjelaskan variabel komitmen organisasi adalah dimensi komitmen organisasi kontunyu kemudian diikuti oleh dimensi komitmen organisasi afektif dan normatif.

(3) Kontruk motivasi kerja pegawai dapat diukur dengan membandingkan antara pekerjaan yang diharapkan dengan pekerjaan yang dirasakan oleh pegawai pada periode waktu tertentu yang dapat dilihat pada lima dimensi, yaitu (a) gaji, (b) pekerjaan itu sendiri, (c) promosi, (d) kerja sama, dan (e) kondisi kerja. Dimensi gaji pegawai paling dominan menjelaskan variabel motivasi kerja, setelah itu baru diikuti oleh dimensi promosi, rekan sekerja, kondisi kerja, dan rekan sekerja.

(4) Kontruk kinerja pegawai pada suatu organisasi dapat diukur dengan membandingkan antara outcome yang dihasilkan oleh seorang pegawai dengan outcome standar yang telah ditentukan oleh organisasi selama periode waktu tertentu yang dapat dilihat pada delapan dimensi, yaitu dimensi (a) kuatitas pekerjaan, (b) kualitas pekerjaan, dan (c) pengetahuan kerja, (d) kreativitas, (e) kerja sama, (f) kemandirian, (g) inisiatif, dan (h) kualitas personal. Akan tetapi dimensi kinerja pegawai yang paling dominan menjelaskan variabel kinerja pegawai adalah dimensi kemandirian kemudian diikuti oleh dimensi kualitas personal, kreativitas, kerja sama, pengetahuan kerja, kualitas kerja, dan kuantitas kerja.

Hasil uji analisis SEM pada Tabel 2 menunjukkan bahwa kompetensi dan komitmen organisasi berpengaruh positif dan signifikan terhadap motivasi kerja pegawai Pemerintah Daerah Kabupaten di Propinsi Bali baik secara bersama-sama maupun secara sendirian. Pengaruh dari kompetensi dan komitmen organisasi terhadap motivasi kerja sebesar 0,3880 (38,80\%), sedangkan pengaruh variabel lain di luar kedua variabel ini yang mempengaruihi motivasi kerja pegawai tersebut sebesar $0,6120 \quad(61,20 \%)$. Hal ini juga mengindikasikan bahwa masih terdapat banyak variabel lain yang mempengaruhi motivasi kerja pegawai di luar kompetensi dan komitmen organisasi yang memerlukan penelitian 
lebih lanjut. Variabel lain yang diduga mempengaruhi motivasi kerja pegawai Pemerintah Daerah Kabupaten di Propinsi Bali dan perlu untuk diteliti lebih lanjut adalah (1) budaya masyarakat Bali yang masih menganggap bahwa menjadi pegawai negari sipil akan dapat meningkatkan status sosial, prestise, dan intelektualitas keluarga dalam masyarakat serta adanya kepastian jaminan hidup untuk hari tua (Brata, 1997: 124); (2) karakteristik biografis pegawai, yang meliputi: umur, masa kerja, dan jumlah tanggungan keluarga (Robbins, 2001: 34); dan (3) kondisi sosial kerja serta (4) karakteristik dan strategi desain kerja (Sutermeister, 1976: 62).

Hasil uji analisis SEM pada Tabel 2 juga menunjukkan bahwa kompetensi dan komitmen organisasi secara bersama berpengaruh positif dan signifikan terhadap kinerja pegawai Pemerintah Daerah Kabupaten di Propinsi Bali. Pengaruh bersama dari kompetensi dan komitmen organisasi terhadap kinerja pegawai sebesar 0,5306 $(53,06 \%)$, sedangkan pengaruh variabel lain di luar kompetensi dan komitmen organisasi pegawai sebesar 0,4694 (46,94\%). Hal ini juga mengindikasikan bahwa masih terdapat banyak variabel lain yang mempengaruhi kinerja pegawai di luar kompetensidan dan komitmen organisasi yang memerlukan penelitian lebih lanjut. Variabel lain yang diduga mempengaruhi kinerja pegawai dan perlu untuk diteliti lebih lanjut adalah (1) kepemimpinan (Fulop and Linstead, 1999: 175), (2) teknologi kerja, (Sutermeister, 1976: 78), (3) iklim organisasi (Isaksen and Lauer, 2001:
172), dan (4) budaya organisasi (Kotter and Heskett, 1992: 60).

Berdasarkan hasil uji analisis SEM tampak bahwa motivasi kerja $\left(X_{3}\right)$ berpengaruh positif dan signifikan terhadap kinerja (Y) pegawai Pemerintah Daerah di Propinsi Bali. Pengaruh nyata dari motivasi kerja terhadap kinerja pegawai ditunjukkan dengan koefisien korelasi (keeratan hubungan) pengaruh langsung sebesar $0,5301 \quad(53,01 \%)$ dan sumbangan pengaruh langsung sebesar $28,10 \%$. Sedangkan pengaruh variabel lain terhadap kinerja pegawai sebasar $0,7190 \quad(71,90 \%)$. Fakta ini mengindikasikan bahwa masih terdapat banyak variabel lain yang mempengaruhi kinerja pegawai dalam bekerja di kantor Pemda Kabupaten Propinsi Bali di luar variabel motivasi kerja yang memerlukan penelitian lebih lanjut. Variabel lain yang diduga kuat mempengaruhi kinerja pegawai di luar variabel motivasi kerja adalah (1) kepemimpinan, (2) iklim organisasi, (3) budaya organisasi, dan (4) teknologi kerja

Temuan studi pustaka dan analisis SEM pada Tabel 1 dan 2 ditemukan model kinerja individu pegawai yang berbasis kompetensi, komitmen organisasi, dan motivasi kerja pegawai seperti yang nampak pada Gambar 1 . Pada Gambar 1 terlihat bahwa kompetensi dibentuk oleh empat dimensi, yaitu kompetensi (1) intelektual, (2) sosial, (3) emosional, dan (4) spiritual. Komitmen orgnasisasi dibentuk oleh tiga dimensi, yaitu komitmen organisasi (1) afktif, (2) kontinu, dan (3) normatif yang saling berinteraksi dalam mempengaruhi motivasi kerja dan kinerja pegawai. 
Motivasi kerja dibentuk lima dimensi, yaitu (1) gaji, (2) pekerjaan itu sendiri, (3) promosi, (4) rekan sekerja, dan (5) kondisi kerja. Kinerja pegawai dibentuk oleh oleh delapan dimensi, yaitu (1) kuantitas kerja, (2) kualitas kerja, dan (3) pengetahuan kerja, (4) kreativitas, (5) kemandirian, (6) kerja sama, (7) inisiatif, dan (8) kualitas personal.

Berdasarkan model konseptual pada Gambar 1 dapat dikristalisasikan hubungan antarvariabel melalui tiga tahap: (1) kompetensi yang mencakup kompetensi: intelektual, sosial, emosional, dan spritual serta komitmen organisasi yang mencakup komitmen orgnisasi yang mencakup komitmen organisasi afektif, kontinu, dan normatif berpengaruh terhadap motivasi kerja dan pegawai; (2) motivasi kerja pegawai berpengaruh terhadap kinerja pegawai; dan (3) kompetensi, komitmen organisasi, dan motivasi kerja berpengaruh terhadap kinerja pegawai. Pada tahap: (a) pertama kompetensi dan komitmen organisasi merupakan variabel yang terpengaruh (dependent variable) sedangkan motivasi kerja dan kinerja pegawai sebagai variabel pengaruh (independent variable), (b) kedua motivasi kerja merupakan variabel pengaruh dan kinerja pegawai sebagai variabel yang terpengaruh, dan (c) ketiga kinerja sebagai variabel terpengaruh sedangkan variabel kompetensi, komitmen organisasi, dan motivasi kerja sebagai variabel pengaruh.

Temuan hasil penelitian menunjukkan bahwa (1) konstruk variabel kinerja pegawai dibentuk oleh dimensi kuantitas kerja, kualitas kerja, pengetahuan kerja, kreativitas, kerja sama, inisiatif, dan kualitas personal; (2) konstruk variabel kompetensi pegawai dibentuk oleh dimensi kompetensi intelektual, sosial, emosional dan spiritual; (3) kontruk variabel komitmen organisasi dibentuk oleh dimensi komitmen organisasi afektif, kontinyu, dan normatif; serta (4) motivasi kerja dibentuk oleh dimensi gaji, pekerjaan itu sendiri, promosi, rekan sekerja, dan kondisi kerja. Temuan ini juga memberikan indikasi bahwa (a) kedelapan dimensi kinerja akan dapat membentuk kinerja individual pegawai karena pegawai memiliki dan memenuhi kedelapan dimensi ini yang akan meningkatkan kematangan atau kedewasaanya dalam bekerja baik secara fisik maupun psikologis sehingga produk atau jasa yang dihasilkan akan meningkat baik secara kuantitas maupun kualitas; (b) secara teoritik untuk meningkatkan kompetensi pada diri pegawai dapat dilakukan dengan upaya meningkatkan kompetensi intelektual, sosial, emosional dan spiritual dengan lebih fokus memperhatikan komponen indikator yang membentuknya; (c) untuk meningkatkan komitmen organisasi pada diri pegawai dapat dilakukan dengan upaya meningkatkan komitmen organisasi afktif, kontinyu, dan normatif; dan (d ) kelima dimensi motivasi kerja akan membentuk motivasi kerja pegawai karena pegawai yang harapannya dipenuhi pada kelima dimensi ini akan dapat meningkatkan rasa semangat kerja mereka terhadap pekerjaan yang dilakukannya dan kedewasaan mereka dalam melakukan pekerjaan di masa sekarang dan yang akan datang.

Hasil penelitian menunjukkan bahwa kompetensi dan komitmen 
organisasi berpengaruh positif dan signifikan terhadap motivasi kerja pegawai Pemerintah Daerah Kabupaten di Propinsi Bali baik secara bersamasama maupun secara sendirian. Hal ini berarti kompetensi dan komitmen organisasi secara serempak dan sendirian berperan dalam upaya untuk mendukung kelancaran proses pembentukan motivasi kerja pegawai dalam bekerja di kantor Pemerintah Daerah Kabupaten di Propinsi Bali. Hasil penelitian ini mendukung temuan penelitian empirik dari Ciarrochi et al. (2000: 559) yang menyimpulkan bahwa kompetensi berpengaruh positif dan signifikan terhadap motivasi karyawan. Di samping itu, hasil penelitian ini juga konsisten dengan pernyataan teoritik dari Kaplan and Norton (2000: 112) yang mengungkapkan bahwa kompetensi yang dimiliki oleh seorang pekerja memegang peran yang sangat untuk meningkatkan motivasi kerja terhadap pekerjaan yang dilakukannya.

Hasil uji analisis SEM menunjukkan bahwa motivasi kerja $\left(X_{3}\right)$ berpengaruh positif dan signifikan terhadap kinerja (Y) pegawai Pemerintah Daerah di Propinsi Bali. Motivasi kerja berpengaruh terhadap kinerja pegawai karena pegawai yang memiliki kepuasan kerja tinggi terhadap pekerjaannya akan dapat melakukan pekerjaan dengan tenang, menangani permasalahan dengan cepat, dan memiliki kedewasaan psikologis yang matang dalam bekerja sehingga kualitas dan kuantitas pekerjaan yang dihasilkan akan sesuai dengan standar yang telah ditentukan dan pada gilirannya akan meningkatkan kinerja karyawan (Luthan, 2000: 113). Hasil penelitian ini mendukung temuan penelitian empirik dari Loveman (1998: 29), Ponznanski dan Blinc (1997: 166), Choo and Tan (1997: 214), dan Brayfield dan Crockett (dalam Steer, 1977: 55) yang menyatakan bahwa kepuasan kerja berpengaruh positif dan signifikan terhadap kinerja karyawan.

Temuan model konseptual kinerja individu pegawai yang berbasis kompetensi, komitmen organisasi dan motivasi kerja pada Gambar 1 menunjukkan bahwa kompetensi dan komitmen organisasi saling berinteraksi satu sama lain. Interaksi dari kedua variabel ini memengaruhi motivasi kerja dan kinerja pegawai baik secara langsung maupun tidak langsung. Motivasi kerja pegawai ini juga akan memengaruhi kinerja dan kualitas pelayanan yang diberikan oleh pegawai kepada masyarakat pengguna pelayanan. Model konseptual kinerja individu ini akan berlaku apabila dipenuhinya 5 asumsi, yaitu asumsi (1) peran pekerjaan yang diemban oleh pegawai harus sesuai dengan kapabilitas yang dimiliki, (2) tersedia kesempatan bagi pegawai untuk mengembangkan kreativitasnya, (3) adanya dukungan semangat kerja internal dalam diri pegawai, (4) adanya kepuasan pegawai terhadap aspek pekerjaan aktual yang dilakukannya, dan (5) adanya kejelasan kriteria, standar, dan umpan balik dalam penilaian kinerja. Model ini, di samping bisa diterapkan pada organisasi pemerintah daerah kabupaten sebagai organisasi yang tidak berorientasi pada profit, juga dapat diterapkan pada organisasi bisnis karena inovasi pelayanan internal yang terbentuk dari interaksi antara kapabilitas, kreativitas, dan motivasi kerja internal ini 
merupakan sumber daya internal organisasi yang unik (sulit ditiru oleh pesaing) dan menjadi sumber keunggulan bersaing bagi perusahaan. Penerapan inovasi dalam pelayanan internal akan meningkatkan produktivitas dan kinerja karyawan, serta meningkatkan kualitas produk dan jasa yang dihasilkan oleh perusahaan. Semua ini akan meningkatkan daya saing perusahaan untuk menghadapi kompetitornya di pasar.

\section{PENUTUP}

Berdasarkan hasil pemabahasan pada bagian sebelumnya maka dapat ditarik beberapa simpulan sebagai berikut.

(1) Secara teoritik dan pengujian empirik konstruk variabel kinerja pegawai dibentuk oleh dimensi kuantitas kerja, kualitas kerja, pengetahuan kerja, kreativitas, kerja sama, inisiatif, dan kualitas personal; konstruk variabel kompetensi pegawai dibentuk oleh dimensi kompetensi intelektual, sosial, emosional dan spiritual; kontruk variabel komitmen organisasi dibentuk oleh dimensi komitmen organisasi afektif, kontinyu, dan normatif; serta motivasi kerja dibentuk oleh dimensi gaji, pekerjaan itu sendiri, promosi, rekan sekerja, dan kondisi kerja.

(2) Model konseptual kinerja individual pegawai dibentuk atau dipengaruhi oleh variabel kompetnsi dan komitmen organisasi dengan motivasi kerja pegawai sebagai variabel intervening.

Berdasarkan temuan hasil penelitian, pembahasan dan simpulan di atas disarankan kepada peneliti berikutnya untuk mengembangkan penelitian ini lebih lanjut pada pemerintah daerah kabupaten lainnya agar dapat menguji kehandalan temuan penelitin ini dan bagi pimpinan pemerintah daerah kabupaten di Bali diharapkan untuk meningkatkan kinerja pegawai dengan fokus pada faktor atau dimensi yang membentuk kompetensi, komitmen organisasi, dan motivasi kerja pegawai karena ketiga variabel ini berpengaruh terhadap kinerja pegawai baik secara teorik maupun empirik.

\section{DAFTAR PUSTAKA}

Ainsworth, Murray, Neville Smith, and Anne Millership. 2002. Managing Performance Managing People: Understanding and Improving Team Performance. Printed in Australia by Griffin Press.

Bar-On, Reuven. 2000. Emotional and Social Intelligence: Insight from The Emotional Quotient Inventory. The Handbooks of Emotional Intelligent. Jossey-Bass. A Willey Company.

Becker, Brian E., Mark A. Huselid, and Dave Ulrich. 2001. The Scorecard Linking People, Strategy, and Performance. Harvard Business School Press. Boston. Massahusetts.

Ben-Bakr, K. A., I. S. Al-Shammari, O. A. Jefri, and J. N. Prasad. 1994. Organizational Commitment, Job Satisfaction, and Turnover in Saudi Organization: A Predictive Study. Journal of SocioEconomics. Vol. 23. p. 449-456. 
Burr, Renu and Antonia Girardi. 2002. Intellectual Capital: More Than The Interaction of Competence $x$ Commitment. Australian Journal of Management. Sydney. p. 77-78.

Cohen, Aaron. 1999. Relationship Among Five Form of Commitment: An Empirical Assessment. Journal of Organizational Behavior. Vol. 20.p. 285-308.

Goleman, G.. 1998. Working With Emotional Intelligence. New York. Bantam.

Mochammad, Ismail. 2000. Kualitas Pelayanan Masyarakat: Konsep dan Implementasinya. Lembaga Administrasi Negara. Jakarta.

Newstrom, John W. and Keith Davis. 2002. Organizational Behavior: Human Bahavior At Work. $11^{\text {th }}$ Edition. International Edtion. McGraw-Hill.

Owen, Robert G.. 1991. Organizational Behavior in Education. USA. Prentice-Hall.

Palan, R.. 2007. Competency Management: Mengimplementasikan Manajemen SDM Berbasis Kompetensi Untuk meningkatkan Daya Saing Organisasi. Edisi Bahasa Indonesia. Penerbit PPM.

Petterson, M. G., West, Lawthom, and Nickell. 1997. Impact of People Management Practices on Performance. Institute of Personnel and Development. London.

Pidada, Untari. 2001. Kompetensi Sosial dan Korelatnya. Jurnal Psikologi. Penerbit Fakultas Psikologi Universitas Padjadjaran Bandung. ISSN No. 0853-3598. Vol 8. No. 2. p. 24-35.
Putteril, Martin S.. 1995. A Causal Model of Employee Commitment in A Manufacturing Setting. International Journal of Manpower. Vol. 16. No. 5/6. p. 56-69.

Ratno, Basuki. 2007. Korelasi Antara Motivasi, Knowledge of Entrepreneurship dan Independesi dan the Entrepreneur's Performance pada Kawasan Industri Kecil. Manajemen Usahawan Indonesia. Terakreditasi Dikti. ISSN: 03029859. Halaman 17-33.

Robbins, Stephen P.. 2001. Organizational Behavior. $9^{\text {th }}$ Edition. Prentice Hall International Inc.

Santrock, John W.. 1999. Life Span Development. USA. McGraw-Hill Inc.

Schermerhorn, John, James G. Hunt, and Richard N. Osbron. 1991. Managing Organizational Behavior. Fouth Edition. John Wiley and Sons Inc.

Seniati, Liche. 2001. Hubungan Antara Persepsi dan DiskrepansiPersepsi Karyawan Atas Pengelolaan Sumber Daya Manusia Dalam Organisasi Dengan Komitmen Karyawan Pada Organisasi. Makara. Jurnal Penelitian Universitas Indonesia. Edisi Sosial \& Humaniora. Volume 5 No. 1. p. 9-17.

Soetjipto, Budi. 2002. Manajemen Sumber Daya Manusia: Sebuah Tinjauan Komprehensif (Bagian I). Paradigma Baru Manajemen Sumber Daya Manusia. Editor A Usmara. Penerbit Amara Books. p. 25-38. 
Spencer, Lyle M. and Signe M. Spencer. 1993. Competence Work: Model for Superior Performance. John Wiley and Sons, Inc.

Supriatna, Tjahya. Sistem Administrasi Pemerintahan di Daerah. Peberbit Bumi Aksara. Jakarta.

Susilo, Willy. 2001. Audit SDM: Perpaduan Komprehensif Auditor dan Praktisi Manajemen Sumber Daya Manusia Serta Pimpinan Organisasi/Perusahaan. Penerbit Percetakan Gema Amini.

Sutermeister, Robert A. 1976. People Productivity. Third Edition. McGraw-Hill Book Company. Suwandi dan Nur Indrianto. 1999. Pengujian Model Turnover Pasewark: Studi Empiris Pada Lingkungan Akuntansi Publik. Journal Riset Akuntansi Indonesia. Vol. 2. No. 2. p. 173-195.

Taringan, Antonius. 2003. Tranformasi Model Newgovernance Sebagai Kunci Menuju Optimalisasi Pelayanan Publik Di Indonesia. Manajemen Usahawan Indonesia. No. 02 Th XXXII Februari 2003. ISSN: 0302-9859. Akreditasi: No. 134/DIKTI/KEP 2001. p. 28-34.

Tjakraatmadja, Jann Hidajat. 2002. Peta Riset dan Konsep Manajemen Pengetahuan Sebagai Kerangka Kajian di Bidang organisasi
Belajar dan Manajemen. Studio Manajemen TI-ITB.

Tjiptoherijanto, Prijono. 2001. Profesionalisme Pegawai Negeri Sipil Dalam Era Otonomi Daerah. Manajemen Pembangunan. No. 36 Tahun X. Desember. p. 5-8.

Topping, Keith, William Bremner, and Elizabeth A. Holmes. 2000. Social Competence: The Social Contruction of The Concept. The Handbooks of Emotional Intelligence: Theory, Development, Assessment, and Application at Home, School, and in The Workplace. Reuver Bar-On and James D. A. Parker Editors. Jossey-Bass A Wiley Company. p. 28-39.

Wall, T. D., M. Corbett, R. Martin, C. Clegg, and P. R. Jackson. 1990. Advanced Manufacturing Technology, Work Design, and Performance: A Change Study. Journal Applied Psychology. Vol. 75. No. 6.p. 691-697.

Witting. Amo F. and Gary S. Belkin. 1977. Introduction to Psychology. USA. McGraw-Hill Inc.

Zohar, Danah and lan Marshall. 2000. Spiritual Intelligence The Ultimate Intelligence. Bloomsbury Publishing Plc. 